\title{
Modernization and Culture in Azerbaijan: Second Half of the XIX Century: Beginning of the XX Century
}

\section{Mubariz Suleymanli}

Professor of the Azerbaijan State Culture and Art University, Baku, Azerbaijan

\begin{abstract}
The end of the 19th century and the beginning of the 20th century, characterized by the expansion of enlightenment, development of education, press and art in Azerbaijan, marked by many cultural events, went down in history as the formation of national thought and national statehood. But these facts have been ignored for many years, and were presented from a subjective and biased point of view during the Soviet times. However, the cultural heritage of that period, especially the reforms implemented in 19181920 to give equal rights to all citizens, regardless of ethnic, religious and political affiliation, gender, state attributes and reforms in education, science and culture, restored the state independence of the Azerbaijan people. In this sense, the study of cultural processes and modernization in Azerbaijan, including cultural reforms during the Azerbaijan Democratic Republic (1918-1920) is relevant both in the terms of studying historical experience and the successful implementation of cultural construction and integration into the world in modern times. The main purpose of the study is to explore the cultural basis of the process of historical renewal and modernization in Azerbaijan, to use the results of this experience in building a modern democratic civil society. The cultural analysis of modernization processes in Azerbaijan became the object of research in the article and the problem was evaluated from the standpoint of East-West conceptual ideas, the logical results of the enlightenment process resulting from the establishment of the Republic were summarized and the main directions of cultural construction in the republic were highlighted.
\end{abstract}

Keywords---ancient culture, Azerbaijan culture, Eastern culture, foreign languages, modernization, national culture, national language, native language, press, school, theater, world culture.

Linguistics and Culture Review (c) 2021.

Corresponding author: Suleymanli, M.; Email: mubariz_suleymanli@yahoo.com

Manuscript submitted: 17 April 2021, Manuscript revised: 9 June 2021, Accepted for publication: 5 July 2021 


\section{Introduction}

Isolating the history of Azerbaijan from the all Turkic history and culture has always been the main goal of purposeful policies. During the Soviet period, a significant number of cultural events were either completely hidden from the people or presented in a distorted form. In particular, in the XIX-XX centuries the cultural heritage of Azerbaijan is presented from subjective and biased positions. Therefore, after the restoration of Azerbaijan's independence, there has been a enlivening in the field of objective research and promotion of the national culture history. The destroying of stereotypes created by the Soviet regime allowed for the re-analysis and study of a number of issues. With the restoration of national statehood, real conditions were created for the study of the people's spirituality, historical and cultural past. Since these years, when the process of national selfawareness has intensified, the urgency of studying the dark pages of Azerbaijan culture, the creativity of personalities whose names have long been forgotten by the people, has set new tasks for researchers. The research on various aspects of the second half of the XIX century and the beginning of the XX century, which is considered a period of modernization in the history of modern AzerbaijanAzerbaijan culture, began (Zarghami et al., 2011; Miraldi et al., 2001).

In the late XIX and in the beginning of XX centuries, activities to apply modern Western values and institutions in Azerbaijan went down in cultural history by various names such as "renewal", "modernization", "westernization". On the basis of this hundred-year process of renewal, the cultural movement in the Azerbaijan society, which entered a new century, began to take on a national image with all its openness. National enlightenment, mother-tongue education, theater, press, cultural-educational and charitable societies became important cultural factors conditioning the modernization. In such a situation, tasks such as benefiting from modern European values formed the basis of national ideology. This national ideology arised from the political nature of the tasks facing the Azerbaijan people, who restored state independence in the late twentieth century (Hovland et al., 1997; Gardner et al., 1998). The main purpose of the investigation is to study these national-ideological principles, which have not lost their relevance for the Azerbaijan society, as it was then. The study of the process of modernization, in which the tradition of historical heritage and the experience of the national statehood is passed on to future generations, is the scientific main point of the research. The theoretical and methodological basis of the research is the principles of historical-comparative cultural analysis. The presentation of historical events includes a chronological sequence and a method of scientificcritical approach (Fang \& Liu, 2002; Cooper, 2000).

\section{Cultural analysis of the process of enlivening in the Azerbaijan society}

The fact of national-cultural revival that took place in Azerbaijan in the beginning of XX century, of course, was not a sudden, ready-made cultural event. This renaissance was an enlivening movement that gradually formed throughout XIX century. Undoubtedly, the influence of the awakening and enlivening processes of the previous century on the development of progressive intellectuals of the national-cultural revival is undeniable. Until that time, a large "cultural movement" stage of enlightenment and national struggle started in Azerbaijan 
with A.A. Bakikhanov, M.Sh.Vazeh, I.Gutgashinli and continued with M.F. Akhundzade and H.B. Zardabi. There was a short period of "political movement" represented by such intellectuals like A. Huseynzade, A. Topchubashov, A. Agaoglu, M.A. Rasulzade, M.B. Mammadzade, N.B.Yusifbeyli. In this sense, the unity of national and human values was the source of the idea of modernization and socio-political meetings. The idea of such a cultural idea was based on the cultural achievements of the East over the centuries (Playán \& Mateos, 2006; Buttel 2000).

The intellectuals of that time benefited from the European democratic thought, they developed these ideas in accordance with the new historical conditions and skillfully applied them to the Azerbaijan environment. These intellectuals did not limit their creativity not only to national traditions, but also sought ways to rise to the level of modern world culture. Therefore, their worldviews are formed in the context of the values of Eastern culture and the achievements of universal civilization (Costenbader \& Markson, 1998; Kowalski \& Limber, 2007). Adopting the world experience, they tried to synthesize national and moral values and it opened wide opportunities to raise the Azerbaijan society to the level of the requirements of the new era.

Those who study the process of enlivening divide this historical stage into two periods - "the Awakening" and "the Enlivening". Thus, the first half of the XIX century is called the "Awakening" era, and the second half - the "Enlivening" era. For example, Hussein Baykara compared this stage with the Renaissance and Reformation processes in Europe, "the social and economic conditions of these two epochs were undoubtedly different" (Baykara, 1966; Qarayev, 2002). The fact of such a cultural awakening must be assessed in the context of both socioeconomic conditions and socio-political factors. From the first years of the XIX century, under the tsarist empire regime Azerbaijan Turkism was trapped in the grip of biased and chauvinist policy. Isolating the Turkic peoples from each other, denying their ancient culture and hindering their development were among the main goals of the Tsarist Empire's policy. Such a policy was largely implemented through the religious, scientific, and cultural activities of tsarism. Thus, from the first years of the occupation, the settlement of the Russian and Armenian population in Azerbaijan, being of Tbilisi as the administrative center and the placement of educational institutions there hindered the formation of a cultural environment. Measures that would complicate national unity and cultural development were the main point of tsarism. Along the way, religious means were not forgotten, and sectarian strife was fueled by policy (Rasulzadeh, 1991).

The religious organization, which was established under the name of a clerical office and became an official government institution, trained "sheikhs of Islam" for Shiites and "muftis" for Sunnis. "Ali" and "Omar" schools were established, and those who practiced the Sunni sect were taught in "Omar" and Shiites in "Ali" schools. "The biased difference between the Georgian aristocracy and the Azerbaijan nobility was not overlooked in this organization, which was a hotbed of controversy for the Muslim community. Like the Georgian patriarch and the Armenian Catholicos, Muslims also had "sheikhs" and "muftis" (Resulzadeh, 1993). However, when it came to their rank and respect, their biased policies against Muslims were evident”. 
While Armenian and Georgian clerics were considered people representing the church and the community, Islamic clerics were demoted to the rank of tsarist official, even less paid than a police officer. While the Georgian aristocracy and the Armenian Church, which had their origins and evolution in their national histories along with tsarist services, played an important role in the lives of these two neighboring nations, the Caucasian nobles and "notebook mullahs" had no role in Azerbaijan national life (Resulzadeh, 1990).

Research works that give a political and cultural picture of that period (Mammadzade, 1992; Resulzadeh, 1993; Resulzadeh, 1990) emphasize that this was done by two important means. It is stated that tsarism pursued a policy of russification, on the one hand, by subordinating the scholars and mullahs of Islam, and on the other hand, without permitting the national spirit and upbringing (forcing the people to study in Russian schools). To achieve its first goal, tsarism established two separate clerical divisions for Shiites and Sunnis. Through this department, he also involved mullahs and efendis in the service of his subordinate officials. In order to achieve the second goal, he opened "ushkols" (schools) on the basis of the russification program. However, the people did not trust the government officials, the mullahs, and the boys who had graduated from Russian schools. The people called the mullahs who were officials of the tsarist government the "notebook mullahs" and the young people who studied in the Russian "ushkol" (school) the "Russian children" and fought against the russification policy in their own way, they set his "akhund" and "school" against the "notebook mullah" and the "Russian school" (Eastridge et al., 2009; Kawiana et al., 2018).

Despite all the prohibitions of the occupation period and the biased policy of the empire, the people of Azerbaijan were able to gradually open the way to the general progress of the cultural world. Thus, along with the negative manifestations of tsarist policy, there were a number of positive factors that had an impact on the national and cultural awakening of the people. For example, by the beginning of XIX century the revolutionaries who were exiled to the Caucasus and the opposition intellectuals who were influenced by the French Revolution, including "the Decembrists" (Russian aristocratic revolutionaries who having connections with Saint-Petersburg revolution of December 26, 1825), each of whom spoke several Western languages, had a great influence to local people. However, what they wanted was no different from a "constitutional tsarist administration" in Russia. It was these ideas of Western freedom that the revolutionaries conveyed to the Azerbaijan intelligentsia. "The cultural idea brought to Azerbaijan by the Russian revolutionaries, who fought against the tyrannical Russian tsarist regime and whose heads were full of Western freedom ideas" Baykara (1966), did not pass unnoticed in public opinion.

The renewal and cultural movement in Azerbaijan began in such a way. One of the factors that stimulated was the growth of prominent personalities in the Azerbaijan environment. For example, Mirza Kazim Bey, who was criticized for his religious beliefs, proved with his works and activities that "he remained patriotic son of Azerbaijan and the East" (Baykara, 1966). The Azerbaijan enlightenment, represented by A. Bakikhanov, I. Gutgashinli, M.Sh.Vazeh, the promotion of individual freedom, the struggle against superstition and despotism is prominent. 
They hoped that by acquiring science and enlightenment, "social evils, including cultural backwardness, could be avoided. If the heads of state are wise and enlightened people, if the human intellect is the criterion in everything, it is possible to achieve common prosperity" (Qarayev, 2002). M.F.Akhundzadeh and his followers considered the cultural development as the main condition and basis of modernization.

Even under the current conditions of tsarism, A.A. Bakikhanov submitted a project to the tsarist government to open a school and said that "everything in the world is connected with science" (Baykara, 1966). Mirza Shafi Vazeh opened the first modern school in Ganja, where a reformer like Mirza Fatali was brought up. Mirza Kazim bey compiled a textbook for children and pointed out the necessity of opening a school. Ismayil bey Gutgashinli and Gasim bey Zakir always fought against ignorance. On the basis of these renewal activities was the issue of school and the elimination of ignorance. These innovative intellectuals worked hard to free the people from ignorance and modernize society.

Changes in the general picture of economic and political life have also been one of the factors contributing to the cultural revival. Thus, from the end of the XIX century, the Russian Empire allowed foreign capital to enter the Russian Empire, and European capitalists began to come to Azerbaijan. Nobel, Rothschild, Siemens, Vishau and others had bought oil fields at a very high price. Some of the oil fields were discovered by Russian capitalist like Kogorev, Shibayev, Bengendorf, Chubonin and others, and Armenians like Mirzoyev, Sarkisov, Kukasov and others captured oil minings. The capitalists sell Azerbaijan's oil, copper, salt, agricultural products and so on, they transported th raw materials to Russia and Western countries. Azerbaijanians in this industry were H.Z.Tagiyev, Musa Nagiyev, Murtuza Mukhtarov, Shamsi Asadullayev, Mirbabayev and others. "Baku had already become an industrial city in the European sense" (Zeynalzade, 2004). During these years, fierce competition began between local capitalists and foreign capitalists. In the struggle against foreigners, the local capitalists felt a great need for a national intelligentsia (Peter, 2015).

Due to these factors, as well as under the influence of various revolutionary theories that have been leaking into the socio-political thought of Azerbaijan since the 70 s and 80 s of the XIX century, solidarity with the national spirit and progressive intellectuals began to form. Their support of educational and cultural activities, establishment of charitable societies, support the press and publishing houses, and other issues were born from these needs (Mehmetzade, 1991). Since "Caucasus" and "Caspi" newspapers pay more attention to Eastern issues than many Russian newspapers, intellectuals such as M. Shakhtakhtinski, H. Zardabi, S.Mehmandarov, E.Sultanov, T.Bayramalibeyov and A.Agaoglu wrote articles in these newspapers trying to enlighten the people. As a result of such a historical development, at the beginning of the XIX century, Zakir's meaning of "homeland" evolved and merged with the meaning of "nation" towards the end of the century" (Mirahmadov, 2007).

Azerbaijan intellectuals gradually gathered around newspapers and magazines that were considered carriers of public memory. In addition, they began to gather around cultural and educational societies and circles such as "Nijat", "Safa", 
"Adab Yurdu", "Nashri Maarif", "Jamiyati Khayriya" and discussed topical issues. The first reading rooms in Azerbaijan were opened in Baku by Habib bey Mahmudbeyli and Soltan Majid Ganizade. In 1894, Nariman Narimanov got the permission from the Russian governor of Baku for these reading rooms. This event was greeted by Turkish intellectuals and readers of the time. Already in 1887 there were libraries in Shamakhi, Guba, Lankaran. The reading rooms were opened in Nakhchivan on the initiative of M.T.Sidgi, C. Mammadguluzade, G.A. Sharifov and A.M.Akbarov. At the end of the XIX century, bookstores began to open in the regions (Baykara, 1975). Thus, towards the end of the XIX century, "a new social class emerged the industrial bourgeoisie and the European intelligentsia" (Mammadzade, 1992).

During this period, three important events took place that were of special importance for Azerbaijan culture: the foundation of the Azerbaijan theater, press, and a new type of school. In March-April 1873, the first theater troupe led by H.Zardabi and N.Vazirov laid the foundation of the Azerbaijan National Professional Theater with performances "Adventure of Vaziri-khani Lankaran" and "Haji Gara". The second important event was the establishment of the Azerbaijan periodical democratic press "Akinchi" newspaper (1875-1877) published by $\mathrm{H}$. Zardabi. "Just as the Turks achieved the honor of first place in the Islamic world in theater, in this experience, Azerbaijan also won the honor of first place among the Russian Turks" (Resulzadeh, 1993). However, as a result of the biased policy of tsarism, the Azerbaijan Turks waited for the national press for many years after "Akinchi". Although the press gap with "Kashkul" was partially closed, after its closure, intellectuals again achieved their goals with the "East Russia" (19031905). During this period, the majority of intellectuals (M.Shahtakhtli, A.Javanshir, F.Kocharli, E.Sultanov, T.Bayramalibeyov, S.Mehmandarov, N.Narimanov, S.Agamalioglu, A.Agayev) were forced to speak in the non-native language press. They are "Caucasus", "New Review" (Tbilisi, in Russian), "Caspian" (Baku, in Russian), "Hablul-Matin" (India-Calcutta, in Persian), "Ahtar" (Istanbul, in Persian), "Literature", Articles in Nasiri, (Tabriz, in Persian) and Tercuman (Bakhchisaray, in Turkish and Russian) newspapers that deserve special mention.

M.C.Topchubashov and Mirza Kazim Bey wrote in the central Russian press ("Sovremennik", "Rossiya", "Otechestvenniye zapiski", "Sankt-Petersburgskiye Vedomosti"). On July 7, 1905, "Hayat" newspaper was published by A.Topchubashov's publishing house, edited by A.Agaoglu and A.Huseynzade. "Hayat" was the first Turkish-language newspaper in Baku after Zardabi's "Akinchi". In the editorial office of this newspaper, which resonated in the world of press, "Revolutionary, progressive writers of Azerbaijan - N.Narimanov, M.A.Sabir, A.Hagverdiyev, S.Afendiyev, O.Faig, M.Hadi, U.Hajibeyov, F.Kocharli and others was the good turn of A.Agaoglu" (Mirahmadov, 2007; Djumabaeva \& Kengboyeva, 2021). Following "Irshad", the publication of the satirical magazine "Molla Nasreddin", the Bolshevik newspapers "Davat" and "Takamul", and the pedagogical magazines "Debistan" and "Maktab" in the national press raised concerns about censorship.

The third important event was the establishment of the first new Russian-Muslim school in Baku (1887). The establishment and development of these schools is 
primarily associated with the names of S.M.Ganizade (1866-1937) and H.N. Mahmudbeyov (1864-1928). Of course, the new type of schools was not in complete denial of the previous teaching practice. Undoubtedly, the teaching of traditional Eastern madrasa also played a great historical role in the past. But the point was that in the new period, the ancient madrasa remained unchanged and stable, and in the XIX century, the school remained the "main organ" in the Middle Ages. Still, medieval teaching methods, theology and shariat lessons in foreign languages, and scholasticism and primitiveness in the teaching of subjects were increasingly understood as an intolerable archaism. Therefore, the struggle for national language in schools began to manifest itself.

Since that time, radical changes and progress trends have been manifested in the national culture of Azerbaijan. The successors of M.F. Akhundzadeh's school have been active in the fields of progressive national press, theater, school and pedagogical thought, translation, criticism, esthetics and achieved great success. The national enlightenment of the M.F.Akhundzadeh period, which has a theoretical character, gradually gives way to the nationalist-enlightenment, which is characterized by its mass, living and practical features. Founded by A. Gorani and R. Afandiyev a new type of realist children's literature is beginning to emerge. Intellectuals such as A. Chernyayevsky, A. Shaig, S.M. Ganizade, N. Narimanov, $\mathrm{J}$. Mammadguluzadeh worked a lot in the creation of textbooks in the native language on the basis of modern pedagogical principles, translate textbooks from Russian. Interest in folklore is growing, and mass and systematic collection of samples of folk literature is beginning.

The most characteristic feature of the cultural life of this period is the fusion of school and literature, pedagogical and artistic thought. After the theater and the press, the school, which has a strong impact on socio-cultural development, becomes the third main factor of enlightenment. Along with the press, schools and education, intellectuals began to think about the difference between national and religious affiliation difference. Current articles about the name, history and national destiny of the people were published in such newspapers as "Akinchi", "Kashkul", "Kaspi", "Kavkaz", "Baku" and the national language, its history and grammar were studied in schools. Towards the end of the XIX century, as a result of their relations with Russia, intellectuals opened a "cultural window" to the West and tried to modernize Azerbaijan society with new ideas. In this sense, the work of other Turkish communities was coordinated, acted in the spirit of unity and equality, in cooperation with newspapers and magazines such as "Molla Nasreddin", "Fuyuzat", "Irshad", "Hayat", and other media. The pages of other periodicals, including "Tercuman", worked for the same goal" (Erol, 2007; Suroso et al., 2021). Of course, as in any field, innovations in theater, press, school and education were not unequivocally welcomed. Along with the manifestations of tsarist policy, superstition was one of the greatest obstacles to this development.

Among the literary and cultural assemblies organized by prominent intellectuals of this period were M.Sh.Vazeh's "Divani-Hikmet" (Tbilisi), Kh. Sidgi's "Anjumanishuara" (Ordubad), S.A.Shirvani's "Beytus-Safa" (Shamakhi), Kh.Natavan's "Meclisi-uns" gave great contributions to the cultural development of Azerbaijanian society. The music festivals sponsored by Mahmud agha in Shamakhi, having influence in the development of science and art, also played 
an important role in the cultural relations of Azerbaijan. Almost a hundred years have passed since the occupation of Azerbaijan by the Russian Empire. During this period, the goal of tsarism, which pursued a policy of destroying all national organizations, could not be achieved at all. In 1904, with a historic event in the Far East, the bulwarks of the Russian Empire began to crumble. Adapting to European culture, Japan sank a Russian warship coming from the Baltic Sea. The subsequent conquest of Port Arthur and the successive Japanese victories paralyzed Russia.

"This event, which shocked the whole world, especially Russia and the Middle East, shook the empire. The Mujahids of freedom and revolution in Russia stood up. Dissatisfied with the tsarist regime, the crowd joined the movement. Organizations spreading freedom and democratic ideas were established in all sides, which laid the foundation for future revolutions" (Rəsulzado, 1991, p.11). Baku was already in the spotlight with its economic power and cultural progress. Thanks to the oil bourgeoisie, this city rose to the level of the only world city in the Caucasus. This status was transferred to Baku in the XIX century from Tbilisi, the headquarters of the Eastern policy of the Russian Empire. The local bourgeoisie was interested not only in economic issues, but also in the fate of the nation, education and the press, and provided material assistance for the enlightenment of the people. In such an environment, Azerbaijanian intellectuals undertook to solve crucial issues.

Intellectuals such as Alimardan bey Topchubashov, Abdurrahim bey Hagverdiyev, Ismayilkhan Ziyadkhanov, Mammadtagi Aliyev, Asadulla bey Muradkhanov were represented in the First State Duma, which was the first parliament in the political history of Russia. "As for the intellectuals who took into account the interests of the national bourgeoisie in the most important problems of sociopolitical and cultural life, A. Huseynzadeh, A. Agaoglu, A. Topchubashov, S. Ibrahimov were more active in this field" Talibzade (1989), and they also had a strong influence on the growing nationalist youth. The movement of cultural progress in the Azerbaijan society had already begun to take on a national image with all its openness. The beginning of the XX century was already marked by the intensification of the class struggle and the gradual entry of the national liberation movement into a new phase. The solidarity of the national bourgeoisie of Azerbaijan with the nationalist intelligentsia and the struggle of the people against the socialism were also characteristic features of this period.

\section{Manifestations of reformist initiatives in Azerbaijan society}

In the beginning of $\mathrm{XX}$ century the different religious tendencies in Azerbaijan society and the process of searching for national affiliation went in parallel. At the same time, in parallel with Islamism, the development of Turkism directed Azerbaijan people to study their "I". During this period, half of the books published in the Azerbaijan language in the Caucasus were literature directly related to Islam. These were mainly religious books written, compiled, or translated into a heavy and incomprehensible language consisting of a mixture of Arabic, Persian, and some Azerbaijan words, written by the Transcaucasian Mufti Huseyn Efendi Gayibov and the Transcaucasian Sheikh-ul-Islam Huseynzadeh Akhund Ahmad and Akhundzadeh Abdusalam. In 1901, Sheikh-ul-Islam 
Akhundzadeh Abdusalam's three-volume books "Tarixi-mugaddas-enbiya", "Risale-i Umdatul-Ahkam", "Preaching and Admonition", four-volume "Risale-i Zubtadul-Ahkam", in 1904 Baku Shiite Chairman of the provincial assembly and Baku judge Akhund Mirmohammad Karim oglu's "Kitabi-kashful-haqq", a threevolume book entitled "Tafsiri-Qurani-Sharif" has been published" (Talibzade, 1992). These publications usually quoted verses, hadiths and narrations concerning the principles of unity of Muslims and required jihad, at the beginning and end of the book the prayers to His Majesty the Russian tsar, his family, and the welfare of the tsarist kingdom has been written" (Mustafayev, 1973). A. Huseynzadeh wrote to his idea rivals that "it is not pan-Islamism or unified Islam that frightens you, but it is the "danger" of Muslims waking up from their slumber and gaining progress, culture and enlightenment" (Huseynzade, 1997). O.F. Nemanzadeh saw a way out in reforming, modernization building a society that would meet the requirements of the time (Mustafayev, 1973). In general, Ahmad Bey Agaoglu has always been distinguished by his activity and determination among the intellectuals working to save the Muslim society from the crisis and protect it from the biased attacks of the occupying forces.

Even intellectuals with different views did not deny the role of religion in the development of society. However, the fact that they were looking for a way out of the crisis was already a recognition of the weakness of the Muslim community against Western scientific and technological achievements. In this sense, there were three different approaches to the problem of modernization:

- The Conservatives claimed that moral values would be lost with the assimilation of Western culture.

- Extreme Westerners advocated the acceptance of Western culture without exception.

- According to the supporters of other positions, the achievements of scientific and technological progress, cultural innovations should be mastered, spiritual and moral values should be protected.

Although there was solidarity among Azerbaijan intellectuals, there were differences of opinion on certain issues. For example, democratic intellectuals such as A. Huseynzadeh, A. Agayev, A. Topchubashov, M.A. Rasulzadeh acted together with the national bourgeoisie, often referring to Islam regulations. There were also intellectuals who valued this union of national needs from different angles. However, although they conveyed their ideas in different genres and styles, they had the same goals. For example, in 1906-1908, dozens of positive articles, letters and notes about "Molla Nasreddin" were published in "Irshad", most of which were written by the editor A. Agayev himself and prominent guides N.Narimanov, U.Hajibeyov, as well as revolutionaries like M.Mammadyarov, S. Afendiyev and others. The leaders of "Molla Nasreddin" such as J. Mammadguluzadeh and O. Faig wrote publicist articles in "Irshad" gives grounds to express such an opinion.

At the same time, in the XIX-XX centuries religious figures, worthy clerics and theologians (Mir Jafar Mir Mammad Karim, Akhund Mirza Abu Turab, Sheikh Ahmad Salyani, Akhund Yusif Talibzadeh and others) shared the same position with intellectuals for the general welfare and cultural progress of Muslim society. 
In general, despite the disadvantages of the contradictory activities of Azerbaijan intellectuals in the direction of Islamism and Turkism, the process resulted in the formation of national awareness. Even in the early years of the XX century, "the level of ethno-political unity of the Azerbaijanians was very low due to the fact that the sense of religious and regional affiliation in the public awareness of Azerbaijan people clearly prevailed over ethnic identity" (Baykara, 1966).

An Azerbaijanian who did not even know his nationality considered himself a Muslim. In this regard, it is possible to give numerous examples from the writings of intellectuals in the press of that period. In all of these writings, there was a conclusion that although he identified himself as a Muslim, but in fact he is a Turk, and his religion is Islam, his language is a Turkic language, and there is no nation in the name of a Muslim. Such an attitude stemmed from the dominance of Islam in all spheres of public life without exception. Of course, Islam's unconditional monopoly in this area prevented the development of other forms of identity, primarily ethnic unity. The first manifestations of national thinking in the Azerbaijan public opinion began to appear in the end of XIX century. The first attempts to raise the issue of national identity in "Kashkul" and "Kaspi" newspapers, which benefited from the ideas of Hasan bey Zardabi ("Akinchi" newspaper), were an expression of the beginning of this issue in Azerbaijan. In the beginning of XX century, the position of H. Zardabi and "Kashkul" newspaper was supported by a large part of the Azerbaijan intelligentsia. In general, in the beginning of the XX century, the vast majority of Azerbaijanians considered themselves Muslims, not Turks. This was the case in other Muslim nations of the Russian Empire.

The ideas of the reformist intellectuals to eliminate the historical Sunni-Shiite division were a valid basis for their goals. For more than five hundred years, sectarian strife separated the Azerbaijan Turks from the Ottoman Turks, the Crimean, Volga, and Central Asian Turks. It is no coincidence that renewal efforts have focused primarily on Islamic institutions and traditions. The formation of a new social identity was linked to a reconsideration of the Shiite identity. On the other hand, the tsarist government controlled the Muslim population for hundreds of years by reviving sectarian divisions and centralizing the management of religious affairs. Thus, Russian Muslims were being alienated from the idea of unity. Indeed, under these conditions, nationalist intellectuals in Russia, unlike in Turkey, preferred the subject of "transition from community to nation" rather than the "forced historical transition from community to community". Reformist intellectuals believed that this would remove a serious obstacle in the formation of a new identity. For this reason, it is understandable that they make demands in the management of religious affairs, such as autonomy, the settlement of sectarian conflicts, cultural autonomy and legal equality.

However, the reform movement has been a source of new conflicts in Azerbaijan society. It cannot be said that this movement represents a serious attempt to unite Russian Muslims and create a higher level of unity. The development of a modernist interpretation of religion served their purpose. Therefore, it is not surprising that Russian Muslims are more divisive than united. These reformist intellectuals set out a goal of forming a new social identity in a society where the 
sense of religion was stronger than the sense of nationality. This was the main reason why they faced public pressure when they started this work.

\section{The main directions of cultural construction in the republican period}

While discussing the ways of assimilation of Western culture, Azerbaijan intellectuals, on the other hand, paid attention to the promotion of the antihumanist and anti-democratic nature of the ideology of Bolshevism from Russia. The most controversial cultural point was the subject of the Bolsheviks' proletariat "national culture in form and socialist culture in content". Azerbaijan intellectuals, who adhered to a humanist and democratic idea such as the against slogan "National culture is a deception of the bourgeois class" - "National culture in form and national culture in content", did not slow down their struggle in the following periods. During the proclamation of the Azerbaijan Democratic Republic and the adoption of the Declaration of Independence, the formula that the state would be a democratic republic commented on the views of the National Council concerning the classes and the people in general. In the fourth article of the Declaration of Independence, the phrase "without gender distinction" raises a more important issue than religion and class, which was revolutionary for the Eastern world. The national state ideologues interpreted the meaning of this decision in such a way that all women had the same rights and authority as men.

During the republican period, steps were taken to modernize education and integrate it into the world education system, and joint education of boys and girls began. Emphasizing the equal activities of women and men in the field of education, the Ministry of Public Education tried to determine the directions of moral education of girls in women's educational institutions, the form and content of training courses, select more appropriate textbooks and teaching aids, develop methods for assessing girls' knowledge. Because of the activities of a special commission set up to prepare and publish textbooks in the Azerbaijan language in order to accelerate the nationalization of the education system, primary and secondary schools were provided with textbooks in the Azerbaijan language. Based on the order of the Ministers Cabinet dated June 27, 1918, it was accepted that "the state language is Turkic", which is the common language of communication in Azerbaijan, gained official status. On August 28, 1918, the government decided to provide education in the mother tongue in primary and secondary schools. According to this decision, "in all primary schools, education was conducted in the mother tongue, while the state language was taught compulsorily". The theater was nationalized, actors and actresses were invited to the state theater, and the State Turkic Theater was established in Baku.

In March 1919, a special commission on alphabet reform was established under the chairmanship of Khudadat bey Malik-Aslanov. Of the drafts submitted at that time, "only the version presented by the teacher Abdulla Efendizadeh was approved by the parliament and accepted as the basis for a new alphabet". At the 70th session of the Parliament on September 1, 1919, the draft "On the organization of the Azerbaijan Darulfun" was put to a vote and the law on the establishment of the State University in Baku was adopted. In addition, the Museum of Independence, a library network and a cultural society called "Baku Hearth" was established. One of the activities taken to strengthen Turkism in the 
society was the concert programs organized in Baku in late 1918 under the name "Turkic Nights". These events were attended by Tatars, Ottoman Turks, Azerbaijan and Turkish poets and writers, artists and painters. The wide-ranging "Turkic Nights" had the exhibitions dedicated to the ethnography and life of the Turkic peoples, such as "Turkish Hearth", "Turkmen headscarf", "Ateshgah", and "Oriental salons". These programs included pieces from the music of various Turkic tribes, as well as theatrical performances with the participation of poets, artists and actors from Azerbaijan, Turkey and Tatarstan. The titles of the works staged were also interesting: "Azerbaijan's independence", "Turkic types", "Turkic woman's world", "National unity" and others (Süleymanl1, 2006). M.A. Rasulzade acted as the responsible director in "Turkish Nights" concerts.

The decision of 100 Azerbaijan youth to study in foreign universities was also an important event. An authoritative jury consisting of M.A. Rasulzadeh (chairman), Ahmad bey Pepinov, Gara bey Garabeyli, Mehdi bey Hajinski and Abdulla bey Efendizadeh was established under the Ministry of Public Education to select these students. "The students were sent abroad by the Ministry of Public Education; 49 of them were sent to various universities of Germany, 27 of them to France, 4 - to Italy, 1 - to England and 6 - to Turkey. The remaining 13 were to be sent to Russia". However, due to the civil war, it was not possible to send students to Russia.

\section{Conclusion}

The fact of national-cultural renaissance in Azerbaijan in the beginnig of $\mathrm{XX}$ century was not a sudden, ready-made, mastered cultural event. A movement of modernization gradually formed throughout XIX century. In this sense, the influence of the renewal processes of the previous century on the development of progressive individuals is undeniable. From the first years of the XX century, along with the different nature of religious tendencies in the Azerbaijan society, the process of searching for national affiliation went in parallel. At the same time, in parallel with Islamism, the development of Turkism directed Azerbaijanians to study their national identities.

One of the emerging tendencies was to criticize the way of life of the traditional religious population, and sectarian divisions became the first target of criticism. Anti-Shiite sentiments were being developed, especially by reformist intellectuals local bourgeoisie. The desire and idea of the reformers to eliminate sectarian conflicts is, in fact, more than a claim to the realization of religious unity, the idea of cleansing the Azerbaijan society, which has been linked to Persian culture for hundreds of years, from this identity. The idea that the problems of society would be solved if this identity was purified and modern values were assimilated prevailed here.

For the founders of the national statehood of Azerbaijan, the main dimension and criterion of the national state was the national culture. In general, the establishment of the Republic was an unprecedented event in the national history of the Azerbaijan people. In this sense, the application of progressive experience to cultural construction without defining the worthy place of intellectuals in the history of culture, without mastering their scientific-theoretical and practical 
heritage, who made a great contribution to the rise of Azerbaijan cultural thought to the level of national statehood in the beginning of XX century would be deproved of human criteria, national background, system of moral values.

\section{Acknowledgments}

I am grateful to two anonymous reviewers for their valuable comments on the earlier version of this paper.

\section{References}

Baykara, H. (1966). Renewal movements in Azerbaijan: XIX. century (Vol. 16). Turkish Culture Research Institute.

Baykara, H. (1975). History of the independence struggle of Azerbaijan. Azerbaijan Public Publications.

Buttel, F. H. (2000). Ecological modernization as social theory. Geoforum, 31(1), 57-65. https://doi.org/10.1016/S0016-7185(99)00044-5

Cooper, M. D. (2000). Towards a model of safety culture. Safety science, 36(2), 111-136. https://doi.org/10.1016/S0925-7535(00)00035-7

Costenbader, V., \& Markson, S. (1998). School suspension: A study with secondary school students. Journal of school psychology, 36(1), 59-82. https://doi.org/10.1016/S0022-4405(97)00050-2

Djumabaeva, J. S., \& Kengboyeva, M. Y. (2021). Bilingualism and its importance in human life. Linguistics and Culture Review, 5(1), 53-63. https://doi.org/10.37028/lingcure.v5n1.451

Eastridge, B. J., Costanzo, G., Jenkins, D., Spott, M. A., Wade, C., Greydanus, D., ... \& Blackbourne, L. H. (2009). Impact of joint theater trauma system initiatives on battlefield injury outcomes. The American journal of surgery, 198(6), 852-857. https://doi.org/10.1016/j.amjsurg.2009.04.029

Erol, A. (2007). Romanticism in Azerbaijan Poetry. İzmir: Azerbaijan Cultural Association Publications.

Fang, H. H., \& Liu, H. (2002). Effect of $\mathrm{pH}$ on hydrogen production from glucose by a mixed culture. Bioresource technology, 82(1), 87-93. https://doi.org/10.1016/S0960-8524(01)00110-9

Gardner, D. K., Vella, P., Lane, M., Wagley, L., Schlenker, T., \& Schoolcraft, W. B. (1998). Culture and transfer of human blastocysts increases implantation rates and reduces the need for multiple embryo transfers. Fertility and sterility, 69(1), 84-88. https://doi.org/10.1016/S0015-0282(97)00438-X

Hovland, M., Hill, A., \& Stokes, D. (1997). The structure and geomorphology of the Dashgil mud volcano, Azerbaijan. Geomorphology, 21(1), 1-15. https://doi.org/10.1016/S0169-555X(97)00034-2

Huseynzade, A. (1997). Who are the Turks and who they consist of. Baku, Mütərcim, 292 (in Azerbaijani).

Kawiana, I. G. P., Dewi, L. K. C., Martini, L. K. B., \& Suardana, I. B. R. (2018). The influence of organizational culture, employee satisfaction, personality, and organizational commitment towards employee performance. International research journal of management, IT and social sciences, 5(3), 35-45.

Kowalski, R. M., \& Limber, S. P. (2007). Electronic bullying among middle school students. Journal of adolescent health, 41(6), S22-S30. https://doi.org/10.1016/j.jadohealth.2007.08.017 
Mammadzade, M. (1992). National Azerbaijan movement. Baku: Nicat.

Mehmetzade, M. B. (1991). National Azerbaijan Movement. Azerbaijan Cultural Association.

Mirakhmedov, S. M. (2007). Asymptotic normality associated with generalized occupancy problems. Statistics \& probability letters, 77(15), 1549-1558. https://doi.org/10.1016/j.spl.2007.03.035

Miraldi, E., Ferri, S., \& Mostaghimi, V. (2001). Botanical drugs and preparations in the traditional medicine of West Azerbaijan (Iran). Journal of ethnopharmacology, 75(2-3), 77-87. https://doi.org/10.1016/S03788741(00)00381-0

Mustafayev, Q. (1973). Islamic ideology and its criticism in Azerbaijan in the early twentieth century. Baku, Maarif.

Peter, V. F. (2015). Relationship among culture, education and sports. International research journal of management, IT and social sciences, 2(11), 38-42.

Playán, E., \& Mateos, L. (2006). Modernization and optimization of irrigation systems to increase water productivity. Agricultural water management, 80(13), 100-116. https://doi.org/10.1016/j.agwat.2005.07.007

Qarayev, Y. (2002). Azerbaijani literature: XIX and XX centuries (two hundred years completing two thousand years - XIX and XX centuries). Baku "ELM.

Rasulzade, M. E. (1993). Caucasian Turks (Vol. 3). Turkish World Studies Foundation.

Rasulzadeh, MA (1990). The Republic of Azerbaijan. Baku: Elm.

Rasulzadeh, MA (1991). Memories of the conflict with Stalin.

Suroso, A., Hendriarto, P., Kartika MR, G. N., Pattiasina, P. J., \& Aslan, A. (2021). Challenges and opportunities towards Islamic cultured generation: sociocultural analysis. Linguistics and Culture Review, 5(1), 180-194. https://doi.org/10.37028/lingcure.v5n1.1203

Süleymanl1, E. (2006). Azerbaijan Turks in the Nationalization Process (A sociological evaluation from the Russian occupation to the present). Ankara: Ötüken publications, 329 (in Turkish).

Talibzade, K. (1989). Criticism and critics. Baku, Yazıç1, 492 (in Azerbaijani).

Talibzade, K. (1992). Abdullah Shaig's article "Taking the Quran to the Sultan" presented by Talibzade Kamal. Elm newspaper, March 6 (403) (in Azerbaijani).

Zarghami, M., Abdi, A., Babaeian, I., Hassanzadeh, Y., \& Kanani, R. (2011). Impacts of climate change on runoffs in East Azerbaijan, Iran. Global and Planetary Change, 78(3-4), 137-146. https://doi.org/10.1016/j.gloplacha.2011.06.003

Zeynalzade, A. (2004). Baku period of Mirza Bala Mammadzade's life and activity. World of Culture, IX edition, Baku, ASAU, 94-104 (in Azerbaijani). 